\title{
Study of some Indian medicinal plants by application of INAA and AAS techniques
}

\author{
Ram Lokhande $^{1}$, Pravin Singare ${ }^{2 *}$, Mahadeo Andhele ${ }^{1}$, Raghunath Acharya ${ }^{3}$ \\ ${ }^{1}$ Department of Chemistry, University of Mumbai, Mumbai, India \\ ${ }^{2}$ Department of Chemistry, Bhavan's College, Mumbai, India; pravinsingare@,vsnl.net \\ ${ }^{3}$ Radiochemistry Division, Bhabha Atomic Research Centre, Mumbai, India
}

Received 15 September 2009; revised 18 October 2009; accepted 20 October 2009.

\begin{abstract}
Instrumental neutron activation analysis (INAA) and atomic absorption spectroscopy (AAS) techniques were used to analyze 18 elements (K, Mn, Na, Fe, Zn, Cu, Co, Br, Sm, Cl, La, Al, $\mathrm{Cr}, \mathrm{Ca} \mathrm{Cd}, \mathrm{Ni}, \mathrm{Pb}$ and $\mathrm{Hg}$ ) in different medicinal plants often used in Indian Ayurvedic system. The samples were irradiated with thermal neutrons in a nuclear reactor and the induced activities were counted by $\gamma$-ray spectrometry using efficiency calibrated high resolution High Purity Germanium (HPGe) detector. Most of the medicinal plants were found to be rich in one or more of the elements under study. The elemental concentration in different part of medicinal plants and their biological effects on human beings are discussed.
\end{abstract}

Keywords: Instrumental Neutron Activation Analyses; Atomic Absorption Spectroscopy; Medicinal Plants; Trace Elemental Analysis; Inter-Elemental Correlations

\section{INTRODUCTION}

There are many references to the curative properties of several herbs in the ancient Indian literature, Rigveda, though a more detailed account is found in the Atharvaveda from where Ayurveda, the Indian traditional health care system (ayus=life, veda=knowledge, meaning science of life) originated. Fairly comprehensive information about herbs has been recorded in two treatises Charak Samhita and Shusruta Samhita-a base for Ayurvedic system of medicine [1,2]. These herbs are now being increasingly used in cosmetics, food as well as alternative medicine [3]. Some of the ingredients of allopathic and most of the Ayurvedic and Homeopathy medicines are derived from plants. Traditional Indian medical herbs used for strengthening the body immune system are known to have many essential and nutritional elements. Their excess or deficiency may disturb normal biochemical functions of the body [4]. Some western scholars have pursued the analysis of various Indian plants and herbs for their medicinal properties [5]. Most studies on such medicinal plants pertain to their organic contents, viz. essential oils, glycosides, vitamins, alkaloids and other active components and their pharmacological/therapeutic effects. Besides, several organic compounds, it is now well established that many trace elements play a vital role in general well-being as well as in the cure of diseases [6,7]. Several studies have reported elemental contents in plant extracts, which are consumed by us either as an herbal health drink or medicine [8-10]. These elements are presented at varying concentrations in different parts of the plants, especially in roots, seeds and leaves which are used as a dietary item as well as ingredient in the Ayurvedic medicinal preparation. The leaves of the plants are still used in some countries, as for instance, in Malaysia [11], Greece [12] and India [13] particularly for their therapeutic effects. Since these trace elements constitute a minute fraction in different parts of the medicinal plants, a sensitive and reliable analytical technique is a prerequisite for obtaining precise and accurate data.

Considering the importance of trace elements in various human metabolic processes and also considering their curative properties, in the present investigation we have applied one of the sensitive analytical techniques like INAA to study the essential elemental content in different parts of Indian medicinal plants and herbs. The overall impact of these essential trace elements on human health is also discussed. Due to increasing industrialization and environmental pollution, the study was also extended to estimate the level of toxic elements present in these medicinal plant samples. Even though the direct link between the essential elemental content and their curative capacity is not yet established, the experimental data of the present work will be of im- 
mense importance in the synthesis of new Ayurvedic formulations. Also, it will help in deciding the proportion of various active constituents and managing dose of a particular formulation.

\section{EXPERIMENTAL}

\subsection{Sampling}

The various medicinal plants (Table 1) in the form of leaves and roots were collected from and around the Keshav Shrushti, Bhayander and Narsing K. Dube College, Nalasopara, Maharashtra, India. Surface contaminants of the plant samples were removed by washing with deionized water twice and then with deionized double distilled water. The leaves were air dried in a clean drying chamber and then dried at $80^{\circ} \mathrm{C}$ for overnight in an oven. The samples were powdered in agate mortar and passed through 100-mesh sieve. Sampling was done from this powder.

\subsection{Irradiation and Counting}

About 50-80 mg of each sample was sealed in a poly- ethylene cover. Samples, reference standard and control sample were packed together and irradiated in the E8 position of the Apsara reactor, BARC. Irradiation time was varied between $30 \mathrm{~min}$ and $7 \mathrm{~h}$ depending on the half lives of the activation products. The sub-cadmium neutron flux in this position is in the order of $1 \times 10^{12} \mathrm{~cm}^{-2}$ $\mathrm{s}^{-1}$. The samples were also irradiated at Dhruva reactor for $1 \mathrm{~d}$ in order to determine the elemental concentration of the long-lived radionuclides, such as Fe. The short irradiation and counting were conducted at the reactor site followed by spectra unfolding at the Radiochemistry Division of BARC, Mumbai. The radionuclides used for the analysis and their $\gamma$ energies are given in Table 2. All the samples and SRMs were counted at a calibrated sample-detector distance from a HPGe detector (Ortec) with $25 \%$ relative efficiency and $2.1 \mathrm{keV}$ resolution at $1332.5 \mathrm{keV}$ of ${ }^{60} \mathrm{Co}$ line, which was connected, to an IBM PC XT computer system. Most of the short lived isotopes contributing to the dead time belong to the elements present in major $\mathrm{Ca}$ and minor Al levels. The presence of different elements analyzed in various medicinal plants was confirmed by measuring their characteristic $\gamma$-ray energy as well as half lives which are in

Table 1. Medicinal plant samples selected for the study.

\begin{tabular}{|c|c|c|c|}
\hline Sample Number & Local Name & Botanical Name & Parts of plants: Medicinal use \\
\hline 1 & Karranj Beej & Pongamia pinnata & $\begin{array}{l}\text { Seed: Cough, skin diseases, flatulence, diarrhoea, cough, arthritis, } \\
\text { ulcers, wounds, diabetes, inflammation, low back pain, fever, hem- } \\
\text { orrhoids, and anemia. Seed oil is also used as insecticidal, nemati- } \\
\text { cidal and bactericidal }\end{array}$ \\
\hline 2 & Kutaja & $\begin{array}{l}\text { Holarrhena } \\
\text { antidysenterica }\end{array}$ & $\begin{array}{l}\text { Seed: Constipation, Piles, acidity, diarrhoea, dysentery, hemorrhage, } \\
\text { hemorrhoids, amoebiasis, hepatitis and skin diseases. }\end{array}$ \\
\hline 3 & Jaiphal & Myristica fragrans & $\begin{array}{l}\text { Seed: Constipation, in treating dehydration caused by vomiting and } \\
\text { diarrhoea, particularly in cholera. It is used as an excellent sex tonic. } \\
\text { It is used in treatment of insomnia, irritability, depression, skin dis- } \\
\text { eases like ringworm and eczema. } \\
\text { It is aromatic, carminative, digestive, anti-inflammatory, diuretic, } \\
\text { lactagogue, aphrodisiac, hypnotic, hallucinogenic, antispasmodic } \\
\text { and stimulant agent. Helps relieving flatulency, useful in nausea, } \\
\text { stomachache, vomiting, diarrhoea associated with cholera. Also } \\
\text { useful in diseases of the liver, spleen, headaches, palsy and eye trou- } \\
\text { bles. } \\
\text { Nutmeg oil stimulates the heart and circulation, activates the mind } \\
\text { and relives people from fainting spells. The oil has good } \\
\text { anti-inflammatory action, and is also successful in relieving pain, } \\
\text { especially muscular aches and pain, as well as rheumatism. }\end{array}$ \\
\hline 4 & $\begin{array}{l}\text { Krishna } \\
\text { Jiraka }\end{array}$ & $\begin{array}{l}\text { Carum bulbocas- } \\
\text { tanum }\end{array}$ & $\begin{array}{l}\text { Seed: Appetizer, in dyspeptic problems, such as mild, sapstic condi- } \\
\text { tions of the gastrointestinal tract, The Ayurvedic Pharmacopoeia of } \\
\text { India recommended the seed in chronic fevers. Seed oil shows mod- } \\
\text { erate antibacterial and antifungal activity against several bacteria and } \\
\text { fungi. Mixed with alcohol and castor oil, it is used for scabies. }\end{array}$ \\
\hline 5 & Babbul & Acacia arabica & $\begin{array}{l}\text { Fruit: Epilepsy, Insomnia, Diarrhoea, teeth disorders, eczema, tonsil- } \\
\text { litis, conjunctivitis, epiphora, leucorrhoea, used in toothpastes and } \\
\text { gargles. }\end{array}$ \\
\hline
\end{tabular}


Table 2. Radionuclides used for the analysis and their $\gamma$-energies.

\begin{tabular}{cc}
\hline Nuclide & $\gamma$-ray energy in keV \\
\hline${ }^{42} \mathrm{~K}$ & 1524.0 \\
${ }^{56} \mathrm{Mn}$ & 847.0 \\
${ }^{24} \mathrm{Na}$ & 1368.0 \\
${ }^{59} \mathrm{Fe}$ & 1099.0 \\
${ }^{65} \mathrm{Zn}$ & 1115.0 \\
${ }^{64} \mathrm{Cu}$ & 1040.0 \\
${ }^{60} \mathrm{Co}$ & 1332.0 \\
${ }^{82} \mathrm{Br}$ & 776.0 \\
${ }^{153} \mathrm{Sm}$, & 103.0 \\
${ }^{38} \mathrm{Cl}$ & 1642.0 \\
${ }^{140} \mathrm{La}$ & 1596.0 \\
${ }^{28} \mathrm{Al}$ & 1779.0 \\
\hline
\end{tabular}

Thermal neutron flux: $10^{12}-10^{13} \mathrm{n} \mathrm{cm}^{-2} \mathrm{~s}^{-1}$.

good agreement with the literature values. Radioactivity measuring times were chosen not to exceed 0.2 times the half lives of the radionuclide of interest. Long irradiated samples were brought to Radiochemistry Laboratory at Mumbai University and $\gamma$-activity was measured. Counting was followed for 1, 2, 6 and $12 \mathrm{~h}$ at different intervals up to $3 \mathrm{~m}$. Care was taken to obtain maximum elemental information from more than one counting and the reproducibility of data was checked. Elemental concentrations of various Ayurvedic medicinal plants were calculated by relative method using control and reference multielemental standard as comparators.

\subsection{Atomic Absorption Spectrometer (AAS) Measurement}

The samples in the powdered form were accurately weighed and digested in $(5: 1)$ mixture of nitric acid and perchloric acid [14]. After digestion few drops of concentrated $\mathrm{HCl}$ was added. The solution was heated gently and then filtered. The residue was again subjected to digestion and filtrate was collected. The entire filtrate was diluted suitably with distilled deionized water. The dilute filtrate solution was used for analysis of elements of interest $(\mathrm{Cr}, \mathrm{Ca}, \mathrm{Cd}, \mathrm{Ni}, \mathrm{Pb}$ and $\mathrm{Hg}$ ) by AAS (Perkin Elmer 3100 model) using suitable hollow cathode lamps. The elements were analyzed by AAS technique by measuring the absorbance of the species at its resonance wavelength. The concentration of various elements was determined by relative method using A.R. grade solutions of elements of interest. The standard conditions for atomic absorption measurement are represented in Table 3.

\subsection{Quality Control}

To provide quality control biological reference material, namely, Polish CRM Virginia Tobacco Leaves (CTAVTL-2) was used. The concentrations of all the elements investigated in this study are well certified in the reference material. The SRMs of biological origin were ana-
Table 3. Standard conditions for atomic absorption measurement.

\begin{tabular}{ccccc}
\hline Element & $\begin{array}{c}\text { Wavelength } \\
\mathrm{nm}\end{array}$ & $\begin{array}{c}\text { Slit width } \\
\mathrm{nm}\end{array}$ & $\begin{array}{c}\text { Sensitivity } \\
\text { check ppm }\end{array}$ & $\begin{array}{c}\text { Lamp current } \\
\mathrm{mA}\end{array}$ \\
\hline $\mathrm{Cr}$ & 357.9 & 0.2 & 4.0 & 7.0 \\
$\mathrm{Ca}$ & 422.9 & 0.5 & 4.0 & 10.0 \\
$\mathrm{Cd}$ & 228.8 & 0.5 & 1.5 & 4.0 \\
$\mathrm{Ni}$ & 232.0 & 0.5 & 7.0 & 4.0 \\
$\mathrm{~Pb}$ & 283.6 & 0.5 & 20.0 & 5.0 \\
$\mathrm{Hg}$ & 253.7 & 0.5 & 200.0 & 4.0 \\
\hline
\end{tabular}

lyzed for quality control and method validation. It was observed that most elemental contents are within $\pm 10 \%$ of the certified values. Standard deviations were also relatively small. The values listed in Table $\mathbf{4}$ (which are averages of three independent measurements) are having the precision of $\sim \pm 2$ to $10 \%$.

\section{RESULTS AND DISCUSSIONS}

An examination of the data from Table 4 shows that different medicinal plants contain elements like K,Mn, $\mathrm{Na}, \mathrm{Fe}, \mathrm{Zn}, \mathrm{Cu}, \mathrm{Co}, \mathrm{Br}, \mathrm{Sm}, \mathrm{Cl}, \mathrm{La}, \mathrm{Al}, \mathrm{Cr}, \mathrm{Ca}, \mathrm{Cd}, \mathrm{Ni}, \mathrm{Pb}$ and $\mathrm{Hg}$ in various proportions. The variation in elemental concentration is mainly attributed to the differences in botanical structure, as well as in the mineral composition of the soil in which the plants are cultivated. Other factors responsible for a variation in elemental content are preferential absorbability of the plant, use of fertilizers, irrigation water and climatological conditions [15].

An examination of the data from Table 4 indicates that fruits of Babbul contain high $\mathrm{K}(8.79 \mathrm{mg} / \mathrm{g})$, and low $\mathrm{Na}(0.08 \mathrm{mg} / \mathrm{g})$ concentration. The $\mathrm{K}$ content is low in seeds of Kutaja $(1.06 \mathrm{mg} / \mathrm{g})$, while $\mathrm{Na}$ content is to the maximum of $0.90 \mathrm{mg} / \mathrm{g}$ in seeds of Jaiphal. It is important here to note that the regulation of potassium is intimately involved with that of sodium and the two are largely interdependent. Potassium is accumulated within human cells by the action of the $\mathrm{Na}^{+}, \mathrm{K}^{+}$-ATPase (sodium pump) and it is an activator of some enzymes; in particular co-enzyme for normal growth and muscle function [16].

The calcium content in various medicinal plants analyzed varies from $1.58 \mathrm{mg} / \mathrm{g}$ in Karranj Beej to 15.1 $\mathrm{mg} / \mathrm{g}$ in Kutaja. Calcium is essential for healthy bones, teeth and blood $[17,18]$. The health of the muscles and nerves depends on calcium. It is required for the $a b-$ sorption of dietary vitamin B, for the synthesis of the neurotransmitter acetylcholine, for the activation of enzymes such as the pancreatic lypase. The recommended daily dietary allowance of $\mathrm{Ca}$ for children is between 500 and $1000 \mathrm{mg}$, and $800 \mathrm{mg}$ for adults. The appreciable high $\mathrm{Ca}$ content in fruits of Babbul suggests its possible use in toothpastes and gargles to overcome deficiency of $\mathrm{Ca}$. 
Table 4. Elemental analysis of some medicinal plants by NAA and AAS techniques.

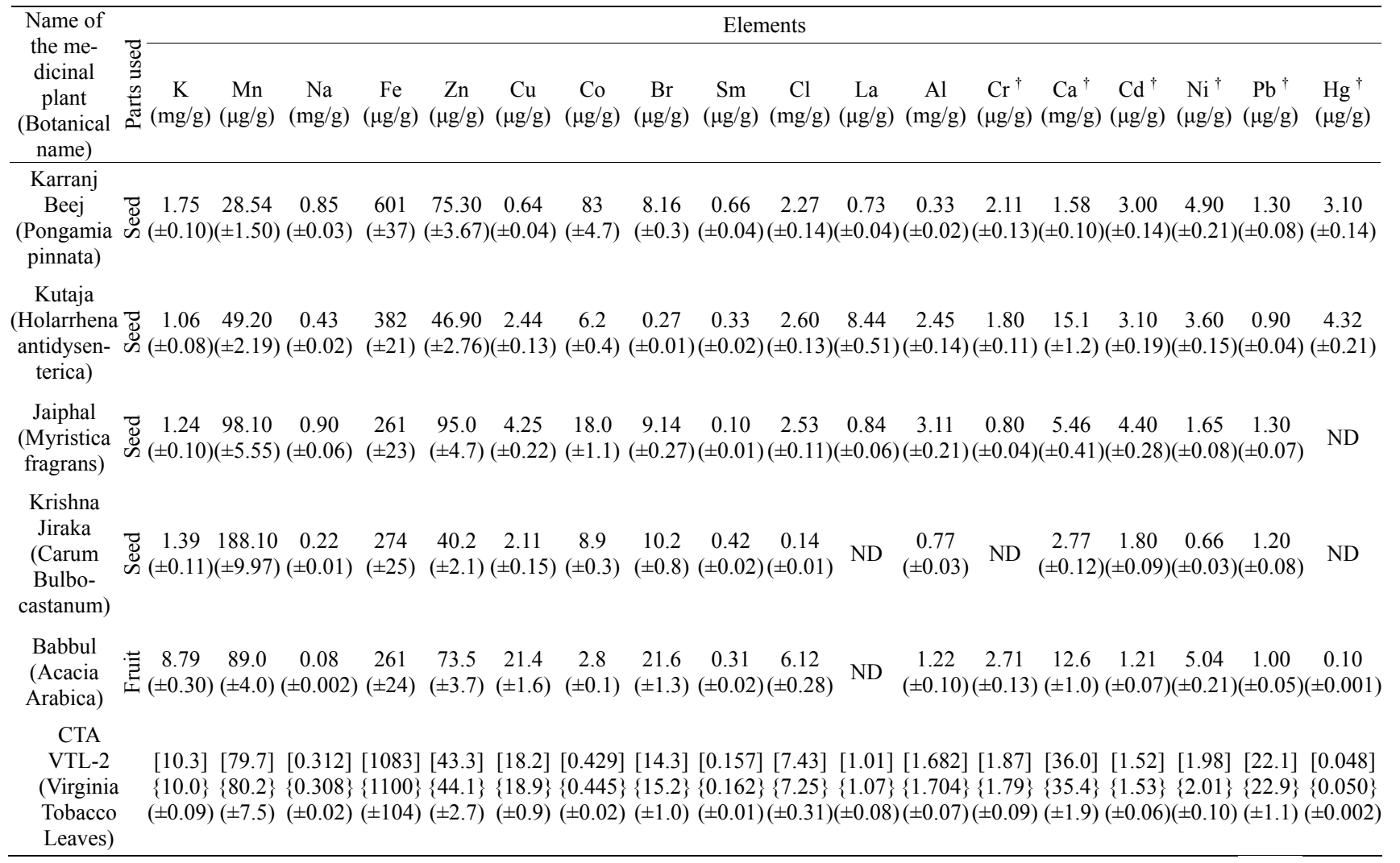

${ }^{\dagger}$ Elements detected by AAS technique; $( \pm$ ) Standard deviation; [ ] Certified values; \{\} Measured values; ND=Not detected.

The elements like $\mathrm{Zn}, \mathrm{Fe}$ and $\mathrm{Cr}$ are essential trace elements (micro nutrients) for living organisms. Zinc is relatively non-toxic [19]. Zinc deficiency is characterized by recurrent infections, lack of immunity and poor growth. Growth retardation, male hypogonadism, skin changes, poor appetite and mental lethargy are some of the manifestations of chronically zinc-deficient human subjects [19]. Zinc is necessary for the growth and multiplication of cells (enzymes responsible for DNA and RNA synthesis), for skin integrity, bone metabolism and functioning of taste and eyesight [20]. From the results obtained, it is observed that the concentration of $\mathrm{Zn}$ ranges from $95.0 \mu \mathrm{g} / \mathrm{g}$ in Jaiphal to $40.2 \mu \mathrm{g} / \mathrm{g}$ in Krishna Jirak. The high concentration of zinc in seeds of Jaiphal suggests its possible use in sex tonic, treatment of worms, skin disease, and eye trouble. The appreciable high $\mathrm{Zn}$ content in Karranj beej and Babbul may also be helpful in treatment of skin disease. Iron occupies a unique role in the metabolic process. The role of iron in the body is clearly associated with hemoglobin and the transfer of oxygen from lungs to the tissue cells [21]. Iron deficiency is the most prevalent nutritional deficiency in humans [22] and is commonly caused by insufficient dietary intake, excessive menstrual flow or multiple births. In this case, it results especially an anemia. In various medicinal plants samples analyzed, the Fe content was observed maximum in seeds of Karranj beej $(601 \mu \mathrm{g} / \mathrm{g})$ and minimum in seeds of Jaiphal and Babbul $(261 \mu \mathrm{g} / \mathrm{g})$. Hence the use of Karranj beej seeds in general tonic preparation may be advised to compensate for treatment of anemia. Chromium plays an important role in diabetes treatment. It is an important element required for the maintenance of normal glucose metabolism. The function of chromium is directly related to the function of insulin, which plays a very important role in diabetes. Chromium is found in the pancreas, which produces insulin. One usable form of chromium is the Glucose Tolerance Factor (GTF) [23], an inorganic compound containing glutamic acid, cysteine and niacin. The absorption of the trivalent chromium in GTF is about 10 to $25 \%$. It enhances the removal of glucose from the blood. The important constituent of GTF is Cr which helps in the potentiating of insulin [24]. Chromium also acts as an activator of several enzymes. Deficiency of chromium decreases the efficiency of insulin and increases sugar and cholesterol in the blood. Chromium deficiency can cause an insulin resistance, impair in glucose tolerance and may be a risk factor in artherosclerotic disease [25]. From the results obtained, it is observed that $\mathrm{Cr}$ content is high in fruits of Babbul $(2.71 \mu \mathrm{g} / \mathrm{g})$ and seeds 
of Karranj beej $(2.11 \mu \mathrm{g} / \mathrm{g})$. Hence the use of this medicinal plant may be advised for the treatment and control of diabetics.

In experiments conducted by Anke et al. [26] with growing, gravid and lactating goats, a poor Br-nutrition $(<1 \mathrm{mg} / \mathrm{g}$ dry matter) led to a significantly reduced growth, a worse conception rate, reduced milk fat production and decreased hemoglobin content. The high concentration of $\mathrm{Br}$ along with $\mathrm{Fe}$ in Karranj beej, Jaiphal, Babbul and Krishna jiraka suggests there possible use in preparation of drugs for curing natural diuretic, phlegm eliminating and stomach invigorating diseases [27] and purifying breast milk. However, further investigations regarding possible essentiality of $\mathrm{Br}$ are necessary due to the fact that $\mathrm{Br}$ accumulates well in plants due to the application of agricultural chemicals such as methyl bromide as fumigant.

The higher Mn content was observed in seeds of Krishna jiraka $(188.1 \mu \mathrm{g} / \mathrm{g})$. It is important here to note that $\mathrm{Mn}$ is an essential element required for various biochemical processes [28]. Mn is also important for several enzymatic processes. It helps in eliminating fatigue and reduces nervous irritability [7,29,30]. Hence use of Krishna jiraka seeds in medicinal preparations may help to supplement Mn for various body functions.

The Co content was observed to be high in Karranj beej $(83.0 \mu \mathrm{g} / \mathrm{g})$. Cobalt is an essential element for the plants having the capability to fix nitrogen in the root tubercles. Animals are able to synthesize vitamin B12, which is the main source of Co in animal foods. Nevertheless, only a part of Co in food derived from animals is present in the form of cobalamines. The recommended daily intake of vitamin B12 for adults is $3 \mathrm{mg}(0.13 \mathrm{mg}$ $\mathrm{Co})$, taking into account that only $50 \%$ is absorbed in the intestine [20]. In humans, deficiency of vitamin B12 leads to a megaloblastic anemia. Cobalt also plays an important role in thyroid metabolism in humans. The higher Co and Fe content in Karranj beej suggests there use in medicinal preparation for treatment of anemia.

The elements like $\mathrm{Hg}, \mathrm{Pd}, \mathrm{Cd}$ and $\mathrm{Ni}$ are supposed to be toxic in nature and their presence in trace amount in various medicinal plant sample analyzed is due to the pollution arising from automobile and industrial activities.

\subsection{Inter-Elemental Correlations}

Several literature reports suggest interrelationship of essential elements like $\mathrm{K}, \mathrm{Na}, \mathrm{Fe}, \mathrm{Co}$ and $\mathrm{Zn}[6,10,14]$. The regulation of metal ion flows, especially of $\mathrm{K}^{+}$and $\mathrm{Na}^{+}$, is crucial to life and is most clearly exemplified by the ionic movements that occur in nerve cells during excitation and transmission of the action potential. The regulation of potassium is intimately involved with that of sodium and the two are largely interdependent. From the experimental data, it is observed that $\mathrm{K} / \mathrm{Na}$ ratio var- ies between minimum of 1.4 in Jaiphal to maximum of 109.9 in Babbul. The result indicates that potassium content is 1.4 times of sodium in Jaiphal, and 110 times in Babbul. The variation of $\mathrm{K} / \mathrm{Na}$ ratio for different plant samples is graphically represented in Figure 1. The transition elements $\mathrm{Fe}, \mathrm{Zn}$ and $\mathrm{Co}$ are well known for their role in biochemical processes [10]. Iron deficiency is common in uremic patients, it causes substantial blood losses. Some reports indicate that dysgeusia, poor food intake, and impaired sexual function, which are common problems of uremic patients, may be improved by zinc supplements [31]. In blood, about $85 \%$ of the zinc combines with protein for transport after its absorption, and its turnover is rapid in the pancreas. Deficiency of zinc causes diabetic hyposima, hypogeusia or coma [15]. The availability of $\mathrm{Zn}$ in the range of $14.8-8.4 \mu \mathrm{g} / \mathrm{g}$ may be beneficial for diabetic patients as its deficiency has been correlated with acute and chronic mal absorption states [30,32]. Similarly Fe is important because it eliminates phlegm and strengthens the function of stomach. Iron is found in body tissue enzymes and helps with energy metabolism. It facilitates the oxidation of carbohydrates, protein and fat to control body weight, which is very important in diabetes [15]. The requirement of Fe for an adult is $20 \mathrm{mg} /$ day and for a child is $10 \mathrm{mg} /$ day. From the result of medicinal plants analyzed, Fe/ $\mathrm{Zn}$ ratio varies from 2.7 in Jaiphal to 8.1 in Kutaja (Figure 2). Cobalt in the form of Vitamin B-12 is in its physiologically active form. It is very essential to provide $3 \mu \mathrm{g}$ per day in the form of Vitamin B-12 for a diabetic individual. A plot of Fe versus Co shows linear relationship (Figure 3) with $\mathrm{r}=0.907$, which represents somewhat poor relationship. It is possible due to the fact that all parts of the medicinal plants are different i.e. seeds and fruits as reported by Razic et al. [33]. In general, it may be mentioned that interrelationship of several elements in medicinal herbs suggest synergistic or antagonistic effects, thus providing various elements to the body in bio-available form in a balanced manner with almost no harmful effects except some environmental contaminants. These, however, should be avoided by collecting herbs grown in a clean and well controlled environment [10].

\section{CONCLUSIONS}

Although there appears to be little knowledge of the precise molecular mechanisms, many Ayurvedic preparations nevertheless appear to demonstrate significant success in treatment of complex diseases. Presumably Ayurvedic medicines contain trace elements in a bio-available form and their impact on the overall pharmacological action cannot be ruled out. Although the direct link between elemental content and curative capability is yet to be established, such studies are vital to understanding the pharmacological action of herbs. The 


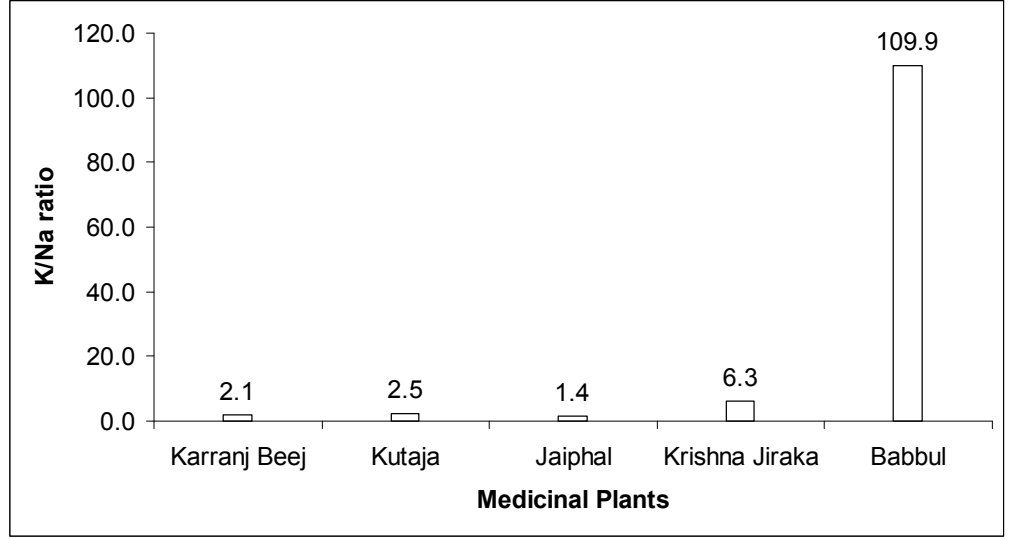

Figure 1. Variation of $\mathrm{K} / \mathrm{Na}$ ratio in different medicinal plant samples.

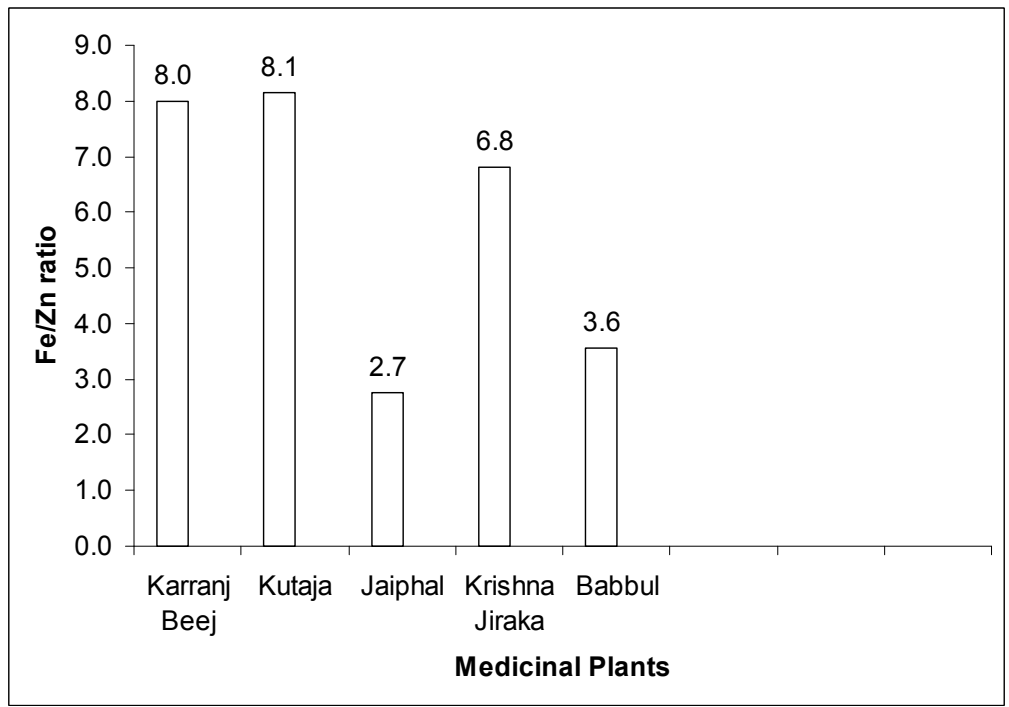

Figure 2. Variation of $\mathrm{Fe} / \mathrm{Zn}$ ratio in different medicinal plant samples.

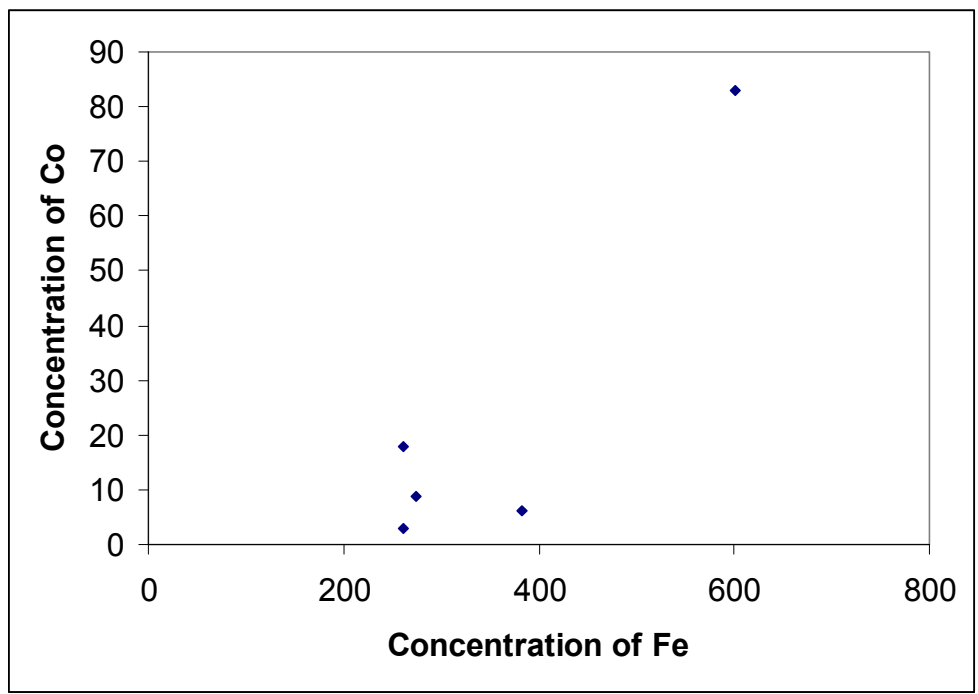

Figure 3. Correlation between $\mathrm{Fe}$ and Co concentrations in different medicinal plant samples. Correlation coefficient $(r)=0.907$. 
data obtained in the present work will be helpful in the synthesis of new Ayurvedic drugs which can be used for the control and cure of various diseases. In order to develop a stronger basis for appreciating the curative effects of medicinal plants, there is a need to investigate, their elemental composition. It has been demonstrated that INAA, with multi-elemental characterization over a wide range of concentration, its blank free-nature and minimum sample preparation is ideal for such studies.

\section{REFERENCES}

[1] Parchure, S.N. (1983) Charak Samhita, Sagar Publications, Pune, 1-3.

[2] Sharma, P.V. (1993) Dravya Guna Vigyan, Chaukhamba Bharati Academy, Varanasi.

[3] Bakhru, H.K. (1998) Herbs that heal natural remedies for good health. Orient Paperbacks, Division of Vision Book Pvt. Ltd, New Delhi.

[4] Lyengar, G.V. (1989) Elemental Analysis of Biological Systems: Biomedical Environmental, Compositional and Methodological Aspects of Trace Elements, Boca Raton, CRC Press, Florida, 1, pp. 242.

[5] Ambasta, S.P. Ed. (1986) The Useful Plants of India, CSIR, New Delhi, pp. 918.

[6] Underwood, E.J. (1977) Trace Elements in Human and Animal Nutrition, 4th Ed, Academic Press, New York, pp. 543.

[7] Prasad, A.S. (1993) Essential and Toxic Elements in Human Health and Disease: An Update, Wiley-Liss, New York.

[8] Powel, J.J., Burden, T.J. and Thompson, R.P.H. (1998) In vitro mineral availability from digested tea: A rich dietary source of manganese. Analyst, 123, pp. 1721.

[9] Abou Arab A.A.K. and Donia, M.A.A. (2000) Heavy metals in Egyptian spices and medicinal plants and the effect of processing on their levels. J. Agri. Food Chem., 48, pp. 2300.

[10] Kumar, A., Nair, A.G.C., Reddy, A.V.R. and Garg, A.N. (2005) Analysis of essential elements in Pragya-peya-a herbal drink and its constituents by neutron activation. $J$. Pharma. Biomed. Anal., 37, pp. 631.

[11] Majid, A.A.B., Sarmani, S., Yusoe, N.I., Wie, Y.K. and Hamzah, F. (1995) Trace elements in Malaysian medicinal plants. J. Radioanal. Nucl. Chem., 195, pp. 173.

[12] Kanias, G.D., Kilikoglou, V., Tsitsa, E. and Loukis, A. (1993) Determination and statistical analysis of trace element and active constituent concentrations in the medicinal plant Eucalyptus Camaldulensis Dehnh (E. Rostratus schlecht). J. Radioanal. Nucl.Chem., 169, pp. 483.

[13] Patel, N.G. (1986) India's traditional medicine: Ayurveda. In: Steiner, R.P. Ed., Folk Medicine: The Art and the Science, American Chemical Society, Washington D.C.

[14] Herber, R.F.M. and Stoeppler, M. Eds. (1994) Trace Element Analysis in Biological Specimens, Elsevier, New York.

[15] Rajurkar, N.S. and Pardeshi, B.M. (1997) Analysis of some herbal plants from India used in the control of diabetes mellitus by NAA and AAS techniques. Appl. Radiat. Isot., 48, pp. 1059.
[16] Birch, N.J. and. Padgham, C (1994) Potassium. In: Seiler, H. G., Sigel, A. and Sigel, H. Eds., Handbook on Metals in Clinical and Analytical Chemistry, Marcel Dekker, New York.

[17] Charles, P. (1992) Calcium absorption and calcium bioavailability. J. Int. Med., 231, pp. 161.

[18] Hughes, M.N. (1972) The Inorganic Chemistry of Biological Processes, Wiley, London.

[19] Prasad, A.S. (1982) Clinical and biochemical spectrum of zinc deficiency in human subjects. In: Prasad, A.S. Ed., Clinical, Biochemical and Nutritional Aspects of Trace Elements, Alan R. Liss, Inc, New York.

[20] Thunus, L. and Lejeune, R. (1994) Cobalt, Zinc. In: Seiler, H.G., Sigel, A. and Sigel, H. Eds., Handbook on Metals in Clinical and Analytical Chemistry, Marcel Dekker, New York.

[21] Sigel, H. Ed. (1978) Iron in model and natural compounds. Metals in Biological Systems, Marcel Dekker, New York, 7.

[22] Reddy, M.B., Chidambaram, M.V. and Bates, G.W. (1987) In: Winkelmann, G., Helm, Van der D. and Neilands, J.B. Eds., Iron Transport in Microbes, Plants and Animals, $\mathrm{VCH}$, New York.

[23] Zetic, V.G. Tomas, V.S. Grba, S. Lutilsky, L. and Kozlek, D. (2001) Chromium uptake by Saccharomyces cerevisiae and isolation of glucose tolerance factor from yeast biomass. J. Biosci., 26, pp. 217.

[24] Anderson, R.A. (1989) Essentiality of chromium to humans. Sci. Total Environ., 86, pp. 75.

[25] Mertz, W. (1982.) Clinical and public health significance of chromium. In: Prasad, A.S. Ed., Clinical, Biochemical and Nutritional Aspects of Trace Elements, Alan R. Liss, Inc, New York.

[26] Anke, M., Groppel, B., Arnhold W., and Larger, M. (1988) Essentiality of the trace element Bromine. In: Briitter, P. and Schramel, P. Eds., Trace Element Analytical Chemistry in Medicine and Biology, Walter de Gruyter, Berlin, New York, 5.

[27] Chen, K.S., Tseng, C.L. and Lin, T.H. (1993) Trace elements in natural drugs determined by INAA. J. Radioanal. Nucl. Chem., 170, pp. 265.

[28] Guenther, W. and Konieczynski, P. (2003) Speciation of $\mathrm{Mg}, \mathrm{Mn}$, and $\mathrm{Zn}$ in extracts of medicinal plants. Anal. Bioanal. Chem., 375, pp. 1067.

[29] Hamilton, E.M.N., Whitney, E.N. and Sizer, F.S. (1994) Nutrition: Concepts and Controversies, 4th Ed., St. Paul, West Publishing Co, MN, USA.

[30] O'Dell, B.L. and Sunde, R.A. Eds. (1997) Handbook of Nutritionally Essential Mineral Elements, Marcell Dekker Inc, New York.

[31] Shils, M.E. and Young, V.R. (1988) Modern Nutrition in Health and Diseases, 7th Ed, K. M. Verghese Co.

[32] Garg, A.N., Kumar, A., Maheshwari, G. and Sharma, S. (2005) Isotope dilution analysis for the determination of Zinc in blood samples of diabetic patients. J. Radioanal. Nucl.Chem., 263, pp. 39.

[33] Razic, S., Onjia, A. and Potkonjak, B. (2003) Trace elements analysis of Echinacea purpurea-herbal medicinal. $J$. Pharm. Biomed. Anal., 33, pp. 845. 